\title{
酵素処理などにより軟化した摂食回復支援食の胃癌術後食としての応用 一初期安全性評価研究一
}

\author{
清水 伸幸 ${ }^{1), 8)}$, 畑尾 史彦 ${ }^{1)}$, 深柄 和彦 ${ }^{2)}$, 大谷 幸子 ${ }^{3)}$, 関根 里恵 ${ }^{3)}$, \\ 朝倉比都美 ${ }^{4)}$, 岡本 智子 ${ }^{5)}$, 稲葉 毅 ${ }^{6)}$, 柴田 近 ${ }^{7)}$, 福島 亮治 ${ }^{6)}$, \\ 佐々木 嚴 ${ }^{7)}$, 瀬戸 泰之 ${ }^{1)}$
}

近年，周術期において絶食期間を短くする栄養管理法が試みられ，経口による早期栄 養摂取再開に関する多くの報告がなされている。しかし食事開始時期を早めるための適 切な食品を探索する試みは未だなされていない。本研究において用いた摂食回復支援食 （以下，「術後食 I 〜 III）は酵素処理を基本技術とする方法により咀嚼困難者用の食事と 同程度の軟らかさに調整されている，術後早期の消化管への負担が少なく，外観が通常 の食事と同様であることから患者の食欲を増進することを期待した．本研究は 20 歳以上 75 歳未満の胃全摘術施行症例で，施設で提供される術後食を術後 4 日目から無理なく摂 食できると判断される症例に対し, 術後 4 9 日目に 3 種類の NPC/N 比の術後食 I 〜 II を順次 6 食ずつ提供し，契食率・自他覚所見・臨床検査デー夕等を採取した。その結 果，術後食 I 〜 II 摂取に起因する有害事象は発生せず，本食品の胃全摘術後食として安 全性が示された。

単群オープン探索的臨床研究, 術後経口摂取支援食, 酵素処理, 安全性評価, 周術期管理

\section{I はじめに}

従来, 消化器癌の周術期には比較的長期間消化 管の安静を保つ必要があると考えられてきた。近 年, こうした考え方とは逆に周術期においても絶

2014 年 11 月 28 日受付: 2015 年 2 月 5 日採用決定 東京大学医学部附属病院胃食道外科 ${ }^{1)}$

同 手術部 ${ }^{2}$

同 栄養管理室 ${ }^{3)}$

帝京大学医学部附属病院栄養部 ${ }^{4)}$

東北大学病院栄養管理室 ${ }^{5)}$

帝京大学医学部外科 ${ }^{6}$

東北大学大学院医学系研究科外科病態学講座生体調節外科 学分野 ${ }^{7}$

国際医療福祉大学山王病院外科 ${ }^{8}$

干 107-0052 東京都港区赤坂 8-10-16

発表学会：第 26 回日本静脈経腸栄養学会
食期間をできる限り短くすることが望ましいとす る栄養管理法が試みられ，胃癌術後においても早 期から消化管を介した栄養管理法である早期経腸 栄養療法が普及してきた ${ }^{1)}$, 2)。また，術後回復を 早めることを目的にした“enhanced recovery after surgery”（以下 ERAS）においても早期経口 による栄養摂取が望まれている3)。これらを背景 に術後における栄養管理方法が見直されつつあ $ろ^{4)}$.

しかしながら，わが国における術後食は従来の 糧食によっており, 食事開始時期を早める適切な 食品を開発する試みはなされてこなかったのが現 状である。本研究において用いた摂食回復支援食 は通常の調理によって作成された食物とほぼ同様 
の外観であるが，酵素処理を基本技術とするさま ざまな方法によりミキサー食などいわゆる咀嚼困 難者用の食事と同程度の軟らかさに調整されてい る。既報において，本法により軟化された食材は 人工消化試験での速やかな崩壊性および易消化性 が報告されている ${ }^{5)}$ したがって，本食材は消化 管への負担が少ないと考えられ，術後の食事開始 を早められる可能性がある。また，外観が通常の 食事と同様であることから，視覚的に患者の食欲 を増進することも期待できると考えている。一方 で, 舌でつぶせる程度の柔らかさではあるもの の, 従来の流動食に比較すれば食材の形状が保た れており，十分な咀嚼がなされず，形状を保った まま嚥下された際に吻合部や消化管へ負担のかか る可能性が考えられる。また, 従来に比較して多 量に食物を摂取することによる腹痛・嘔吐や検査 データの異常などが起こることも懸念事項として 考えられ, 安全性試験が必要である。

術後早期の患者は，体蛋白質の異化が充進して いることが知られている。術後速やかな創傷の治 癒には蛋白質の異化を抑制し同化を促進する必要 があり，高蛋白の術後食が望まれる ${ }^{6)}$.

今回提供した摂食回復支援食は提供するメ ニューの組み合わせにより 3 種類の非蛋白熱量 / 窒素比（以下 $\mathrm{NPC} / \mathrm{N}$ 比）が得られるように調整 した。術後早期には NPC/N 比約 55 (以下「術 後食Ｉ」）に調整したメニューを提供し，順次約 70 (以下「術後食II), 約 100 (以下「術後食 III」）と使い分けることによって，術後の蛋白質 異化直進状態に対応できるものと考えた.

本研究は胃癌に対する胃全摘術後患者を対象 に，術後食 $I \sim \mathbb{I I}$ を提供し，以下の項目に関して 検討することを目的としている。

1）術後食 $I \sim \mathbb{I I}$ 開始後の臨床症状，臨床検査に よる安全性評価

2）アンケート調査による，食事ごとの味・見た 目・満足度

3）喫食率，および喫食率より算出した摂取エネ ルギー, たんぱく質, 脂質, 炭水化物とその
割合

4）術後食 $I \sim \mathbb{I I}$ 提供期間終了後の病院食への移 行状況

\section{III対象と方法}

本研究は単群オープン探索的臨床研究で, 20 歳以上 75 歳未満の胃全摘術施行症例の中で, 1) 術前に文書により説明を受け文書による同意を明 示している，2）施設で提供される術後食 I 〜 II を術後 4 日目から無理なく摂食できると判断され る，3）食事摂取開始後 6 食あがりのステップ アップが可能と研究責任医師が判断した患者を選 択基準とした。除外基準は，1）胃全摘時に合併 切除を行った（胆囊摘出術は許容）, 2) 重篤な肝 障害（AST またはALT 值が施設基準の 2.5 倍を 超える場合）を有する，3）重症糖尿病（HbA1c 值が 8.0 を超える場合), 4) 腎機能異常 (Cr 值 が $2.0 \mathrm{mg} / \mathrm{dL}$ を超える場合/尿たんぱく質定性検 查值が $2+$ 以上を示す場合）を有する，5）食物 アレルギーを有する患者とした。選択基準を全て 満たし, 除外基準に抵触しない患者を本研究の対 象とした。

術前に同意を取得し仮登録を行い,その後に施 行した臨床検査結果により除外基準に抵触しない ことを確認して本登録を行い，研究を開始した。

本研究による栄養管理方法は, 原則として術後 3 日間の輸液管理の後, 術後 $4 \sim 6$ 病日に「術後 食 I」を 2 日間, 術後 $6 \sim 8$ 病日に「術後食 II」 を 2 日間, 術後 8〜 10病日に「術後食亚」を 2 日 間提供する，いわゆる「6 食あがり」を目安とす るが，ステップアップに無理があるなど，患者の 状況によっては「術後食 I， II， III」の各提供日 を 1 日多くすることを許容した。提供したメ ニューの一例を図 1 に示す。術後食 III提供後 は, 各施設が通常同時期に投与している病院食を 提供した。術後食 I 〜 II で補給される熱量, 栄養 素および水分などが不十分であると判断された場 合は根拠を調査票に明記し, 経静脈栄養もしくは 経腸栄養により適切に補給し, その投与量を調査 

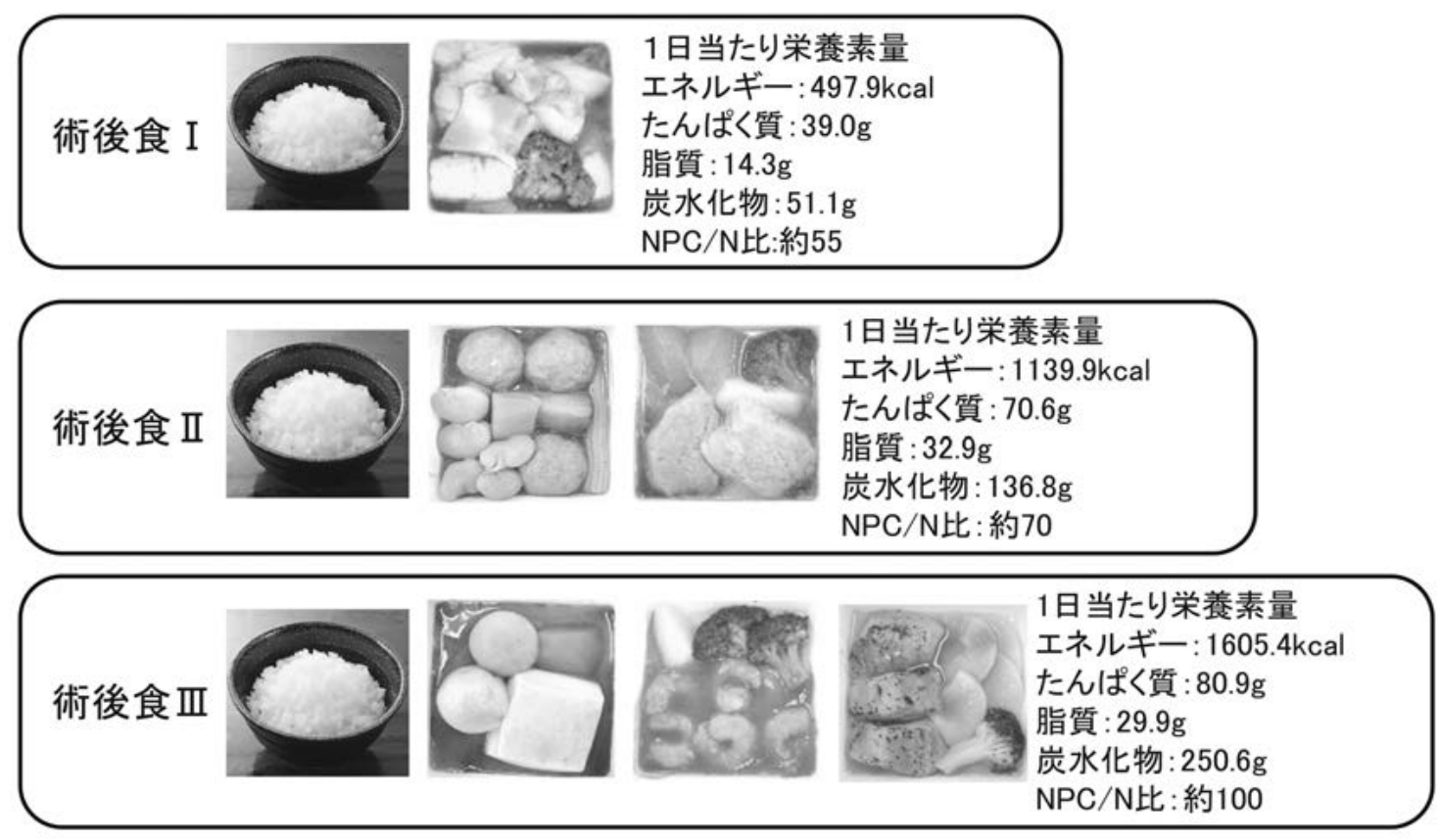

図 1 術後食 $I ＼mathrm{~ I I I の メ ニ ュ ー 一 例 ~}$

票に記載した.

研究期間中は，秤量法による喫食率・6段階法 （選択肢「非常に満足：6」,「満足：5」,「やや満 足 : 4」, 「やや不満 : $3 」$, 「不満 : $2 」$, 「非常に不 満：1」）アンケートによる満足度のほか, 自他覚 所見・バイタルサイン・身体計測・栄養管理状 況・臨床検査（血液，尿）を評価・実施した。臨 床検査は通常の診療で行われている範囲のものに とどめて結果を本研究に用い, 術後食 I 〜 II が胃 癌術後食として安全に摂取できる食品であるか否 かを検討した。

本研究は東北大学病院, 帝京大学医学部附属病 院との多施設共同臨床研究として実施し, 東京大 学大学院医学系研究科倫理委員会にて承認され (受付番号：2964，2010 年 4 月 12 日承認)，共同 研究施設でも各施設の倫理委員会の承認を得て施 行した.

\section{III 結果}

1. 症例背景

実施期間中 9 例が登録され，平均年齢 68.1
表 1 被験者背景（数值は平均值 \pm 標準偏差

\begin{tabular}{ll}
\hline 年齢 (歳) & $68.1 \pm 5.3$ \\
性別 (男 : 女) & $7: 2$ \\
術前体重 $(\mathrm{kg})$ & $60.7 \pm 5.3$ \\
術前 BMI & $23.0 \pm 1.9$ \\
術式 & 胃全摘 $: 8$ 例 \\
& 残胃全摘 $: 1$ 例 \\
合併切除 & 胆囊 $: 3$ 例 \\
アプローチ & 開腹 $: 7$ 例 \\
& 腹腔鏡 : 2 例 \\
手術時間 (分) & $226 \pm 105$ \\
\hline
\end{tabular}

（土5.3）歳, 男女比は7 $: 2$, 術前体重 $60.7 \pm$ $5.3 \mathrm{~kg}$, 術前 BMI : $23.0 \pm 1.9$, 施行術式は 8 例が 胃全摘術，1例が残胃全摘術であった。合併切除 として 3 例で胆襄摘出術が施行された。アプロー チは開腹が 7 例，腹腔鏡が 2 例，平均手術時間は 226（土105）分であった（土以下の值は標準偏 差）（表 1）.

2. 術後食 $\mathrm{I} \sim \mathrm{II}$ 摂取開始後の臨床症状, 臨床検 查および有害事象

術後食 I 〜II摂取開始に伴う自覚症状の発現, 

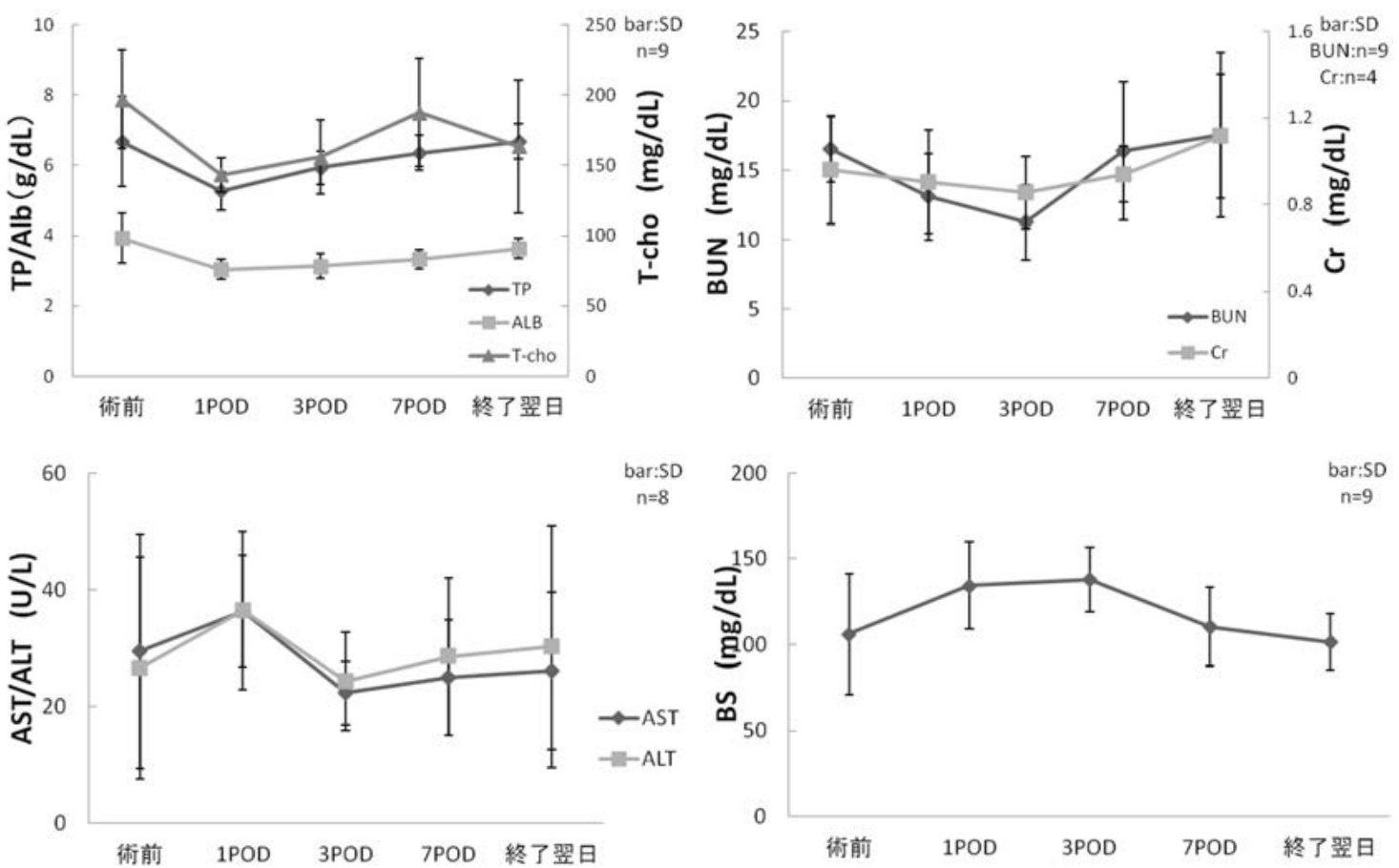

図2 臨床検査值の推移

a. 総蛋白，アルブミン值，総コレステロール值，b．腎機能，c．肝機能，d．血糖值（バーは標準偏差）

栄養状態のマーカーとなる生化学データの悪化や 血糖值の上昇, 肝機能・腎機能障害は認めなかっ た（図 2).

1 例で空腸空腸吻合部狭窄に伴うものと考えら れる腹痛（CTCAE v4.0-JCOG Grade 3） と腹部 膨満感（CTCAE v4.0-JCOG Grade 2) を認め, 1 例で創部痛（CTCAE v4.0 Grade 3）が認められ た。術後食 I 〜 II 摂食に起因すると考えられる有 害事象の発生は認められなかった。

\section{3. アンケート調查結果}

図に示す通り，全般的に患者満足度は高かった が，個人差が認められた（図 3）。

4. 喫食率および喫食率より算出した摂取エネル ギー，たんぱく質，脂質，炭水化物の割合 喫食率は「術後食 I・II」では 7 割を超えてい たが「術後食吕」では 5 割程度に止まった（図 4). 静脈栄養は第 6 病日頃まで維持輸液を中心

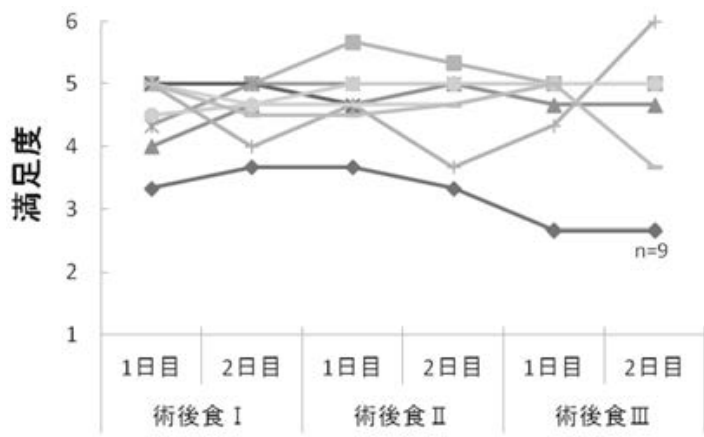

図 3 全体的満足度 各症例の推移

に投与されている症例が多く，静脈栄養を含めた 1 日の総摂取熱量に対する術後食 I 〜 III 寄与率 は「術後食恧」が一番高い值を示した（図 5). 総摂取熱量は各期間で徐々に増加しており，三大 栄養素ごとの各期間の摂取熱量をみると炭水化物 によるエネルギー摂取は術後経過とともに増加し ていくが，たんぱく質と脂質に関しては「術後食 III」を提供した期間に減少しており, 特に脂質で 著明であった（図 6). 


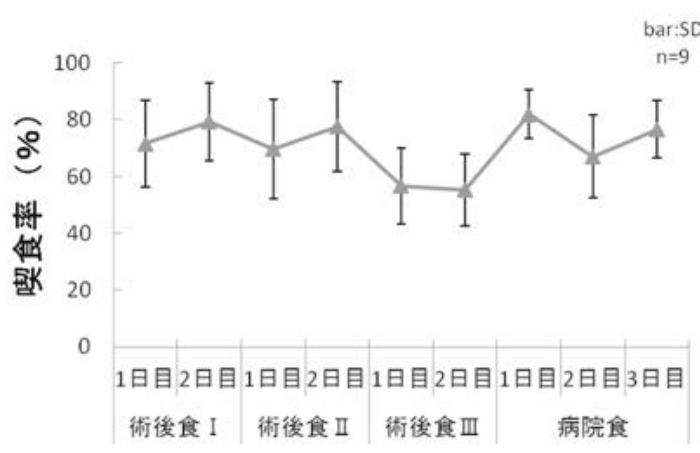

図 4 契食率の推移（バーは標準偏差）
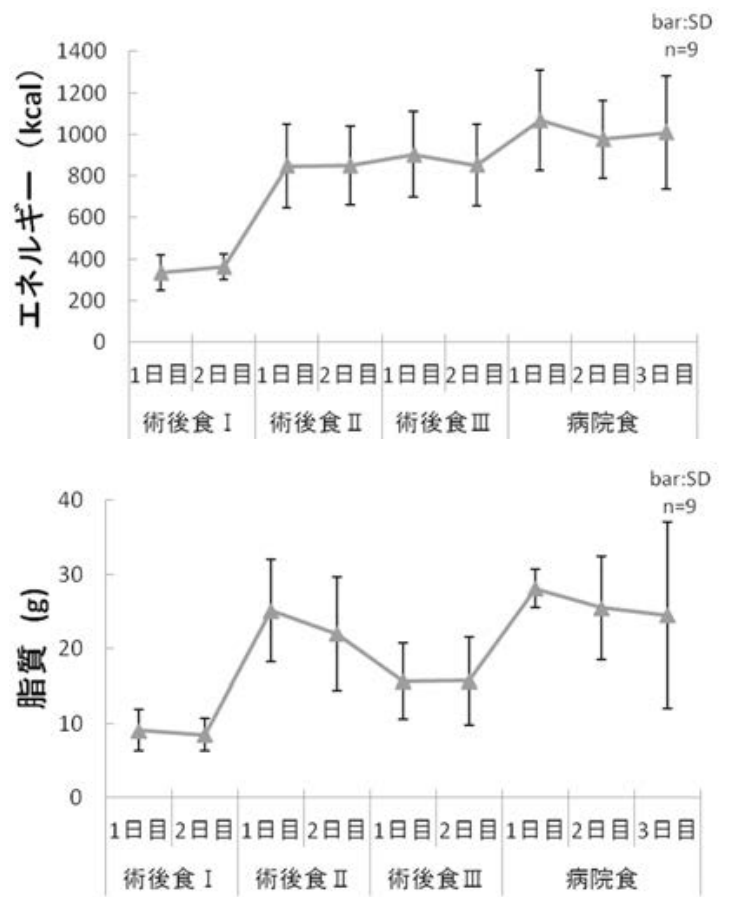

図 6 摂取エネルギー量および三大栄養素量の推移

\section{5. 提供期間終了後の病院食への移行の状況}

図 4,6で示した通り,「術後食III」から病院 食への移行において, 契食率および総摂取熱量の 低下を来すことはなかった。

\section{$\mathrm{IV}$ 考察}

消化管手術前後の栄養管理について, 絶食期間 をできるだけ短くするべきであるとの報告は多 い.この考え方を中心とした周術期管理は ERAS と呼ばれ ${ }^{3)}$, 特に欧米からの結腸癌周術期に関す

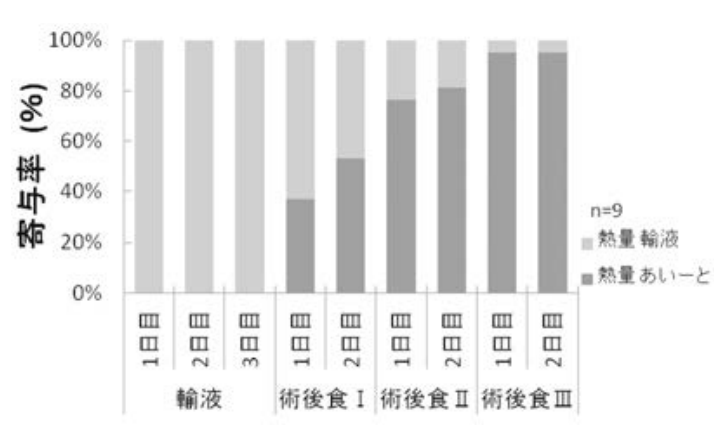

図 5 摂取熱量に対する術後食 $I 〜 \mathbb{I I}$ の寄与率

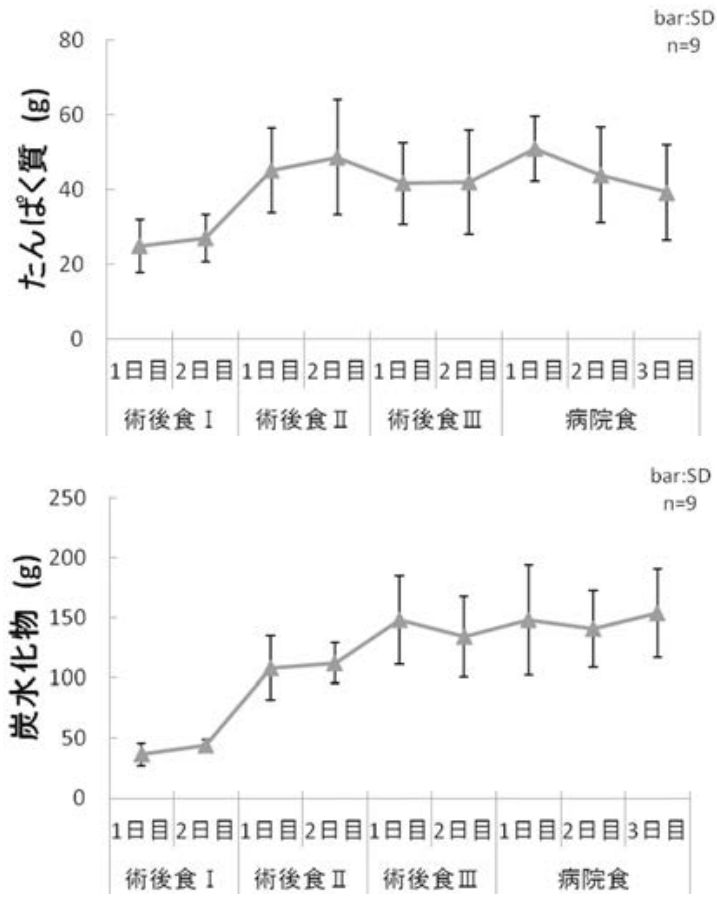

(バーは標準偏差)

る報告が多かった ${ }^{7)}$ 。胃癌周術期の ERASに関し ては Yamada らが，第 2 病日から経口で水分と栄 養剤を投与し第 3 病日から流動食を開始した検討 結果を報告している ${ }^{8)}$. 術後疼痛管理の徹底など も相まって, 経口摂取回復日や排ガス排便の時期 が早くなり，7日目に扮ける体重減少の軽減が示 されている。しかしながら手術 1 カ月目以降では 体重にも差がなく, 術後入院期間に差はなく, 早 期経口摂取再開の有効性を示したとは言い難い. また，術後第 3 病日からの食事が『早期経口摂 
取』と言えるかについても議論の余地がある.

今回検討した血液生化学データは一般的なもの に止めたが，術後の值としては概ね通常の胃全摘 術後と同程度の変化であると考えた，また，有害 事象に関しては, Roux-en-Y 再建症例の空腸空 腸吻合部に起因する通過障害と開腹創の痛みのみ であり，術後食 I 〜 III 摂取が原因と考えられる 有害事象は認められなかったことから，本研究で 用いた摂食回復支援食は胃全摘術後の術後食とし ての使用に耐えうるものと考えられた。

患者アンケートの結果は全体的に高い満足度が 得られたものの，個人差が認められた。今回用い た術後食 I 〜 II は食材がわかりやすく，視覚的に 嗜好を反映した可能性がある。実臨床で活用する 上では，メニューを患者に選択させるなどの検討 が重要と思われる ${ }^{9)}$.

「術後食 III」の提供期間では「術後食 I ・ II 」 と比較して喫食率低下を認めたものの, 摂取熱量 は維持されていた。「術後食正」を供する意義が あるかについては，「術後食I」に引き続いて通 常の病院食を提供した際の喫食率，摂取熱量を検 討する必要があろう。また，「術後食吕」の提供 期間に炭水化物の摂取量は保たれ，たんぱく質と 脂質の摂取量が低下したことに関しては，見た目 で脂質を回避するなどの術後患者の食行動の変化 の可能性も考えられる ${ }^{10)}$ ，食欲に関与する脳腸相 関や ${ }^{11)}$, 食欲に関与するグレリン等の消化管ホル モンの変化 ${ }^{12)}$, 13) や術後消化管運動の検討も必要 と考えて準備を進めている ${ }^{14)}$.

本試験において摂取された，たんぱく質の実測 量は「術後食 I ・ II ・ III」の順に平均で 26 . $47 \cdot 42 \mathrm{~g}$ であった。術後の当該期間に当院で提 供していた術後流動食・三分粥・五分濑の平均的 たんぱく質含有量は $35 \cdot 38 \cdot 46 \mathrm{~g}$ であり, 一般 的に術後の食事摂取量が半量程度であることを勘 案すると，これまでの術後食に比較して多くのた んぱく質を摂取できていると考えられ，術後の蛋 白質異化充進状態にも対応できているものと推察 される。
術後食 I 〜 III提供期間終了後の病院食への移行 においては, 熱量, たんぱく質, 脂質, 炭水化物 の摂取量を下げることなく円滑に食上げすること ができた。われわれの施設における胃癌術後の退 院基準となる食事形態は全弹以上としている。本 研究では, 術後第 4 病日から術後食 I を開始した が，消化管内での易崩壊性，易消化性が期待でき る本術後食をより早期から摂取できれば，より早 期の食上がりとそれによる入院期間の短縮が図れ ると考えられる。本食品に要する費用は，今回の プロトコールでは 1 症例あたり 2 万円程度であ り, DPC 病院であれば入院期間が 1 日短縮され れば症例ごとの医療費は相殺される。社会的にみ れば，入院期間の短縮に伴いベッドの有効利用の メリットが生じると考えており, 現在, 術後早期 の経口摂取開始に関する多施設共同臨床研究を進 めており, 安全性に加え栄養学的, および医療経 済的観点からも評価を行い, 術後の早期経口摂取 の医学的および医療経済学的な重要性を更に明ら かにしていきたい.

本研究内容要旨は第 26 回日本静脈経腸栄養学 会にて報告した。

本研究は $\mathrm{EN}$ 大塚製薬株式会社から委託された 受託研究として施行した.

\section{文献}

1) Lewis SJ, Andersen HK, Thomas S : Early Enteral Nutrition Within 24h of Intestinal Surgery Veasus Later Commencement of Feering A systematic revew and Meta-analysis. J Gastrointest Surg 13 : 569-575, 2009

2) Osland E, Yunus R M, Klhan S et al. : Early Versus Traditional Postoperative Feeding in Patients Undergoing Resectal Gastrointestinal Surgery : A Meta-Analysis. JPEN 35 : 473-487, 2011

3) Baraga M, Ljunggvist O, Soeters P et al. : ESPEN Guideline on Parenteral Nutirition : Surgery. Clin Nutr $28: 378-386,2009$

4) Suehiro T, Matsumata T, Shikada Y et al. : Accelerated rehabilitation with early postoperative oral feeding gastrectomy. Hepatogastroenterology 51 : 1852-1855, 2004 
5）東口高志：保形軟化食品あいーとの開発とその物性評 価ならびに人口消化液浸漬試験による崩壊性と消化性 の検討。静脈経腸栄養 26 : 95-106, 2010

6) Mimura Y, Yamakawa M, Maeda J et al. : Efficacy of amino acid infusion for improving protein metabolism after surgery : a prospective randomized study in patients undergoing subtotal gastrectomy. J Am Coll Surg $185:$ 163-171, 1997

7) Varadhan KK, Neal KR, Dejong CHC et al. : The enhanced recovery after surgery (ERAS) pathway for patients undergoing major elective open colorectal surgery : A meta-analysis of randomized controlled trials. Clinical Nutrition 29 : 434-440, 2010

8) Yamada T, Hayashi T, Cho H, Yoshikawa T et al. : Usefulness of enhanced recovery after surgery protocol as compared with conventional perioperative care in gastric surgery. Gastric Cancer 15 : 34-41, 2012
9）関根里恵, 大谷幸子, 清水伸幸ほか：術後食の形態を 再考する。臨床栄養 $118 ：$ 458-464, 2011

10）可児富子, 入山圭二：消化管手術に伴う味覚閾值の変 動. 静脈経腸栄養学会 $25: 53-59,2010$

11）藤宮峯子：グレリン，デスアシルグレリン，オベスタ チンによる上部消化管運動の制御と脳腸相関. 医学の あゆみ $235 ： 951-953,2010$

12）足立真一, 瀧口修司, 宮崎安弘ほか：栄養療法におけ るグレリンの役割. 臨床外科学会誌 $66: 798-804$, 2011

13）日浦祐一郎, 瀧口修司, 森 正樹ほか：胃切除術後の グレリン投与の効果. Surgery Frontier 19：112-114, 2012

14）今井賢治, 市川由美子, 塩見真由美ほか：消化器外科 領域における胃電図の臨床応用に関する検討。外科 65 : 1219-1229, 2003 


\title{
Application of an eating recovery assisting food cooked soft
} enzyme treatment technology for the postoperative diet of gastric surgery patients-Safety Assessment-

\author{
Nobuyuki Shimizu ${ }^{1,8)}$, Fumihiko Hatao ${ }^{1)}$, Kazuhiko Fukatsu ${ }^{2)}$, Sachiko Ootani ${ }^{3)}$, \\ Rie Sekine $^{3)}$, Hitomi Asakura ${ }^{4)}$, Tomoko Okamoto ${ }^{5)}$, Tsuyoshi Inaba ${ }^{6)}$, \\ Chikashi Shibata $^{7)}$, Ryoji Fukushima ${ }^{6)}$, Iwao Sasaki ${ }^{7)}$, Yasuyuki Seto ${ }^{1)}$
}

\begin{abstract}
Recently, nutritional care that shortens the fasting duration has been performed during the perioperative period and numerous studies on the early resumption of oral intake have been reported. However, evaluations to explore suitable meals for advancing the start of oral intake have not been undertaken. For food intake recovery support meals (hereinafter referred to as postoperative diet I - III) used in this study, the softness of the meal is adjusted to the same level as the difficulty of mastication for the patient consuming the meal using a method which is based on enzyme treatment technology.

The burden on the gastrointestinal tract of postoperative diet I - III in early post-operative patients is low, and since the appearance of the meal is similar to normal meals, an increase in the appetite of patients was expected.

This study targeted patients between the ages of 20 and 75 years old who underwent total gastrectomy and were able to eat postoperative diet provided by the hospital from postoperative day 4 . Patients were sequentially provided 6 meals of postoperative diet I - III with 3 different NPC/N ratios from postoperative days 4 to 9 . Information such as food intake rate, subjective and objective opinions, and clinical laboratory data were collected.

In this study, since no adverse events were observed after consuming postoperative diet I III, the safety of these meals after gastrectomy was demonstrated.
\end{abstract}

eating recovery assisting food, enzyme treatment technology, safety assessment

\footnotetext{
Division of Stomach and Esophagus Surgery, The University of Tokyo Hospital, Tokyo, Japan ${ }^{1)}$

Surgical Center, The University of Tokyo Hospital, Tokyo, Japan ${ }^{2)}$

Department of Nutrition, The University of Tokyo Hospital, Tokyo, Japan ${ }^{3}$

Nutrition and food Services, Teikyo University Hospital, Tokyo, Japan ${ }^{4)}$

Department of clinical nutritional management, Tohoku University Hospital, Miyagi, Japan ${ }^{5)}$

Department of Surgery, Teikyo University School of Medicine, Tokyo, Japan ${ }^{6)}$

Division of Biological Regulation and Oncology, Department of Surgery, Tohoku University Graduate School of Medicine, Miyagi, Japan ${ }^{7)}$

Surgery Department, Sanno Hospital, International University of Health and Welfare, Tokyo Japan ${ }^{8}$

8-10-16 Akasaka, Minato-ku, Tokyo, 107-0052, Japan
} 